Article

\title{
Content and Dietary Exposure Assessment of Toxic Elements in Infant Formulas from the Chinese Market
}

\author{
Chuanyou Su ${ }^{1,2}$, Nan Zheng ${ }^{1}$, Yanan Gao ${ }^{1}$, Shengnan Huang ${ }^{1}$, Xue Yang ${ }^{1}$, Ziwei Wang ${ }^{1}$, \\ Hongjian Yang ${ }^{2}$ and Jiaqi Wang ${ }^{1, *}$ \\ 1 Ministry of Agriculture-Laboratory of Quality and Safety Risk Assessment for Dairy Products (Beijing), \\ Institute of Animal Science, Chinese Academy of Agricultural Sciences, Beijing 100193, China; \\ suchuanyou2010@126.com (C.S.); zhengnan@caas.cn (N.Z.); gyn758521@126.com (Y.G.); \\ hsnigot7@163.com (S.H.); yangxue234723@126.com (X.Y.); wswzw12@163.com (Z.W.) \\ 2 College of Animal Science and Technology, China Agriculture University, Beijing 100193, China; \\ yang_hongjian@cau.edu.cn \\ * Correspondence: wangjiaqi@caas.cn; Tel.: +86-10-62816069
}

Received: 19 October 2020; Accepted: 26 November 2020; Published: 10 December 2020

\begin{abstract}
In this study, the content of chromium $(\mathrm{Cr})$, arsenic $(\mathrm{As})$, cadmium $(\mathrm{Cd})$ and lead $(\mathrm{Pb})$ in domestic and imported infant formulas from Beijing, China were analyzed using inductively coupled plasma mass spectrometry. The content of $\mathrm{Cr}$, As, $\mathrm{Cd}$ and $\mathrm{Pb}$ was 2.51-83.80, 0.89-7.87, 0.13-3.58 and $0.36-5.57 \mu \mathrm{g} / \mathrm{kg}$, respectively. Even though there were no significant differences in toxic elements content between domestic and imported infant formulas, $\mathrm{Cd}$ content was slightly lower in domestic samples. The estimated daily intake (EDI), target hazard quotient (THQ) and hazard index (HI) were calculated for infants between 0.5 and $5 \mathrm{y}$ of age. The EDIs were lower than the oral reference doses. THQ of As, Cr, Cd and Pb was 0.027-0.103, 0.024-0.093, 0.0025-0.0090 and 0.0015-0.0046, respectively. HI values were $0.055-0.192$ for boys and $0.056-0.209$ for girls and were inversely associated with age with a threshold $<1$. The non-carcinogenic risk value were in the safe range, indicating that exposure of $\mathrm{As}, \mathrm{Pb}, \mathrm{Cr}$ and $\mathrm{Cd}$ from infant formulas do not represent a health risk in China.
\end{abstract}

Keywords: infant formula; toxic elements; risk assessment; target hazard quotient

\section{Introduction}

The optimum nutrition for newborns is breastmilk. However, for the past two decades, approximately $67.0 \%$ of infants are not completely breastfed for the recommended six months [1]. In China, only $20.8 \%$ are completely breastfed for six months, $11.5 \%$ are breastfed for one year and $6.9 \%$ are breastfed for two years [2]. Infant formulas play a special role in infant nutrition because they can be used as a breastmilk substitute [3]. Suitable infant formulas are preferred sources of nutrition for most infant when breastmilk is absent or insufficient [4]. There are a variety of infant formulas in the Chinese market. In 2017, the import of infant formulas was substantial (296,014 t, \$3.98 billion) [5].

According to the International Agency for Research on Cancer, arsenic (As), cadmium (Cd) and hexavalent chromium (Cr VI) are group 1 carcinogens (2012), inorganic lead (Pb) is a group 2A carcinogen (2006) [6]. Epidemiological and experimental evidence indicates that combination effects generated by multi-heavy metals might be quite different from that induced by the same individual metal, because heavy metals at individual low acting concentrations can elicit higher toxicity on interactions [7-9]. Pandya et al. [7] showed that under similar dosages, when $\mathrm{Pb}$ and $\mathrm{Cd}$ are present together, the toxic effect is antagonized by co-exposure due to possible competition among $\mathrm{Pb}$ and $\mathrm{Cd}$ for hepatic accumulation. Su et al. [10] found that combination of different heavy metals showed certain adverse effects on the hematologic, hepatic, renal and neurobehavioral function and could also 
disturb electrolyte and lipid balance in rats. This suggests that joint toxicity or interaction patterns among different heavy metals should be taken into consideration during the risk assessment for the exposure to multi-heavy metal simultaneously. The gut immune barrier is the first line of defense against any potentially harmful agents that have been ingested in food [11]. Contrary to the restricted macromolecular passage in adulthood, enhanced transfer takes place across the intestines during early life, due to the high endocytic capacity of the immature intestinal epithelial cells during the neonatal periods [12]. Young individuals are particularly sensitive to chemical contaminants due to their high exposure-body weight ratio [13], immunodeficiency and intestinal hypoplasia. Compared to adults, children have a greater risk to heavy metal exposure through milk consumption [14,15]. Long-term exposure to these toxic elements may cause significant health problems.

To protect public health, maximum levels (MLs) for toxic elements have been set by international organizations and China. The ML of Pb in foods for infant and young children has been set at $150 \mu \mathrm{g} / \mathrm{kg}$ by China [16], $10 \mu \mathrm{g} / \mathrm{kg}$ by Codex Alimentarius Commission (CAC) [17] and $50 \mu \mathrm{g} / \mathrm{kg}$ by the European Union, which set the ML of Cd at $10 \mu \mathrm{g} / \mathrm{kg}$ [18].

Based on the toxicity, frequency of occurrence and potential for human exposure, the Agency for Toxic Substances and Disease Registry developed a substance priority list. According to this list, As, $\mathrm{Pb}, \mathrm{Cd}$ and $\mathrm{Cr}$ are the 1st, 2nd, 7th and 17th priority food contaminants, respectively [19]. In China, toxic elements in food have to be measured to ensure food safety [20]. Therefore, it is of utmost importance to measure the content of toxic elements in infant formulas [21,22]. A previous study reported that certain milk powders and infant formulas are contaminated with toxic elements [21,23]. Recently, toxic elements in infant formulas have been reported in Tanzania [21], Egypt [24], Nigeria, UK, USA [25] and Portugal [13]. Dietary exposure to toxic elements in adults and young individuals has been assessed in many countries [26-30]. In our previous study, toxic elements in raw milk in China have been assessed [31]. However, the domestic and imported infant formulas have not been systematically investigated. Therefore, consider the scarcity, the aim of this study was to (i) determine the toxic elements (heavy metals and arsenic) contamination in infant formulas (stages 1 through 4) in Beijing, (ii) check whether these samples meet legal requirements, (iii) compare toxic elements in domestic and imported samples, (iv) evaluate the exposure to toxic elements from infant formulas and to assess the potential health risks to infants in China.

\section{Materials and Methods}

\subsection{Sampling}

A total of 93 cow milk-based infant formulas from Beijing were collected in 2019-2020 (Table 1). Among those formulas, 27 were domestic and 66 were imported. For domestic brands, Feihe, Junlebao and Yili were selected. For imported brands, Illuma, Arla, Abbott, Nestle, HiPP, Biostime, Nutricia, Friesland, Meadjhnson, Wyeth, Anmum, Karihome and a2 were selected. These samples cover large swathes of the infant formula market in Beijing. Furthermore, there were stage 1 (28), stage 2 (27), stage 3 (24) and stage 4 (14) infant formulas. Samples were sampled in supermarkets. The samples were maintained at $-20^{\circ} \mathrm{C}$ prior to analysis.

Table 1. Sample characteristics.

\begin{tabular}{ccccc}
\hline \multirow{2}{*}{ Country } & \multicolumn{4}{c}{ Stage } \\
\cline { 2 - 5 } & $\mathbf{1}$ & $\mathbf{2}$ & $\mathbf{3}$ & $\mathbf{4}$ \\
\hline China & 8 & 8 & 8 & 3 \\
Ireland & 2 & 2 & 2 & 2 \\
Denmark & 2 & 2 & 1 & 0 \\
Germany & 2 & 2 & 1 & 0 \\
France & 1 & 1 & 1 & 0 \\
Netherlands & 9 & 9 & 8 & 9 \\
Switzerland & 1 & 1 & 1 & 0 \\
New Zealand & 3 & 3 & 2 & 0 \\
Total & 28 & 27 & 24 & 14 \\
\hline
\end{tabular}




\subsection{Sample Analysis}

To $0.5 \mathrm{~g}$ infant formula sample in a polyfluoroalkoxy digestion vessel, we added $1 \mathrm{~mL}$ deionized water (Milli-Q, Millipore, Bedford, MA, USA), $5 \mathrm{~mL}$ of $\mathrm{HNO}_{3}$ (65\%, Suprapur, Merck, Darmstadt, Germany) and $2 \mathrm{~mL}$ of $\mathrm{H}_{2} \mathrm{O}_{2}$ (30\%, Suprapur, Merck, Darmstadt, Germany). Following an overnight pre-digestion at room temperature, the mixture was digested in a microwave-assisted reaction system (CEM MARs 6, Charlotte, NC, USA) according to the program shown in Table 2. Once cooled to room temperature, the digest was diluted with deionized water to $25 \mathrm{~mL}$ and analyzed by inductively coupled plasma mass spectrometry (ICP-MS; Agilent 7700 Series ICP-MS, Agilent Technologies, Santa Clara, CA, USA) after filtration through a $0.22-\mu \mathrm{m}$ membrane.

Table 2. Microwave-assisted digestion procedure.

\begin{tabular}{ccc}
\hline Temperature $\left({ }^{\circ} \mathbf{C}\right)$ & Gradient Temperature Time $(\mathbf{m i n})$ & Holding Time $(\mathbf{m i n})$ \\
\hline 90 & 10 & 5 \\
140 & 10 & 10 \\
190 & 10 & 20 \\
\hline
\end{tabular}

We developed standard five-point calibrations for each of the toxic elements. The correlation coefficients were $>0.999$ and the limits of detection for $\mathrm{Pb}, \mathrm{As}, \mathrm{Cr}$ and $\mathrm{Cd}$ in infant formula was $0.2,0.5$, 2.0 and $0.1 \mu \mathrm{g} / \mathrm{kg}$, respectively. To assess the accuracy of the method, milk powder certificate reference material (CRM, Code: GBW 10117, National Institute of Metrology, Beijing, China) were analyzed. The recovery of the elements from milk powder CRM is shown in Table 3. The recovery of these four toxic elements was $92.3 \%-104.3 \%$.

Table 3. Quality control of certified reference material, milk powder.

\begin{tabular}{cccc}
\hline \multirow{2}{*}{ Toxic Elements } & \multicolumn{3}{c}{ Certified Reference Material } \\
\cline { 2 - 4 } & Certified Values $(\mu \mathrm{g} / \mathbf{k g})$ & Observed Values $(\boldsymbol{\mu g} / \mathbf{k g})$ & Recovery $(\%)$ \\
\hline $\mathrm{Cr}$ & 1900 & 1753.70 & 92.3 \\
$\mathrm{As}$ & 200 & 192.40 & 96.2 \\
$\mathrm{Cd}$ & 111 & 115.77 & 104.3 \\
$\mathrm{~Pb}$ & 416 & 397.28 & 95.5 \\
\hline
\end{tabular}

\subsection{Risk Assessment}

The risk of toxic elements for infants ( 0.5 to $5 \mathrm{y}$ of age) was assessed by calculating the estimated daily intake (EDI), target hazard quotient (THQ) and hazard index (HI). All experimental procedures for this study were approved by the ethics committee of Chinese Academy of Agricultural Sciences.

\subsubsection{Exposure Assessment}

The exposure of infants to toxic elements from infant formula consumption was assessed using the average content of toxic elements in the test and the recommended average consumption of infant formula in China [4] according to Equation (1) [27].We compared the EDI obtained in this study with the reference dose (RfD). RfD is useful as a reference point from which to gauge the potential effects of the chemical at other doses. Usually, doses less than the RfD are not likely to be associated with adverse health risks and are therefore less likely to be of regulatory concern [29].

$$
\mathrm{EDI}=\mathrm{C} \times \mathrm{DI} / \mathrm{BW}
$$

where $\mathrm{C}$ is the toxic elements content in infant formula $(\mu \mathrm{g} / \mathrm{kg})$, DI is the daily infant formula intake $(\mathrm{kg})$ and $\mathrm{BW}$ is body weight $(\mathrm{kg})$. 


\subsubsection{Target Hazard Quotient (THQ)}

The potential chronic risk from toxic elements was expressed as THQ. THQ value was used to assess non-carcinogenic risk. THQ values $<1$ indicate that consumers are unlikely to experience any adverse health effects. If the THQ value $\geq 1$, there is a potential health risk. It was calculated using Equation (2)

$$
\mathrm{THQ}=\mathrm{EDI} / \mathrm{RfD}
$$

where RfD is the oral reference dose $(\mathrm{mg} / \mathrm{kg} / \mathrm{d})$, based on $3 \times 10^{-4}, 4 \times 10^{-3}, 3 \times 10^{-3}$ and $1 \times 10^{-3}$ for $\mathrm{As}, \mathrm{Pb}, \mathrm{Cr}$ and $\mathrm{Cd}$, respectively [30,32-35].

\subsubsection{Health Risks of Multiple Toxic Elements}

In this study, total THQ was also estimated because people usually suffered combined effects expose to several pollutants [32]. The total potential chronic risk from multiple toxic elements was expressed as a hazard index (HI), which was calculated using Equation (3). $\mathrm{HI}<1$ indicated no risk for human health $[14,36]$.

$$
\mathrm{HI}=\sum \mathrm{THQ}
$$

\subsection{Statistical Analysis}

Data analysis was performed using SPSS (IBM, Endicott, NY, USA) version 20. Data were expressed as mean \pm standard error (SE). Differences in heavy metal content among samples were analyzed with an independent $t$-test. $p<0.05$ was considered statistically significant.

\section{Results and Discussion}

\subsection{Concentrations of Toxic Elements in Infant Formula}

A total of 93 infant formula samples were sampled in China and comprehensively measured 4 toxic elements. Samples, which belonged to nine countries, were for different infant growth stages. The content of toxic elements in infant formulas were $27.38 \mu \mathrm{g} / \mathrm{kg} \mathrm{Cr}(2.51-83.80 \mu \mathrm{g} / \mathrm{kg}), 3.32 \mu \mathrm{g} / \mathrm{kg}$ As $(0.89-7.87 \mu \mathrm{g} / \mathrm{kg}), 0.98 \mu \mathrm{g} / \mathrm{kg} \mathrm{Cd}(0.13-3.58 \mu \mathrm{g} / \mathrm{kg})$ and $2.03 \mu \mathrm{g} / \mathrm{kg} \mathrm{Pb}(0.36-5.57 \mu \mathrm{g} / \mathrm{kg}$; Tables 4 and 5).

Table 4. Heavy toxic elements $(\mu \mathrm{g} / \mathrm{kg})$ in infant formulas of different stages.

\begin{tabular}{cccccccccc}
\hline \multirow{2}{*}{ Stage } & \multirow{2}{*}{$\mathbf{N}$} & \multicolumn{2}{c}{$\mathbf{C r}$} & \multicolumn{2}{c}{ As } & \multicolumn{2}{c}{$\mathbf{C d}$} & \multicolumn{2}{c}{$\mathbf{P b}$} \\
\cline { 3 - 9 } & & Mean & Range & Mean & Range & Mean & Range & Mean & Range \\
\hline 1 & 28 & 27.09 & $2.51-67.70$ & 3.00 & $0.89-7.87$ & 0.88 & $0.16-3.53$ & 1.61 & $0.42-4.82$ \\
2 & 27 & 26.71 & $8.12-58.33$ & 3.57 & $1.09-6.34$ & 1.01 & $0.18-2.62$ & 2.19 & $0.81-5.45$ \\
3 & 24 & 27.39 & $4.81-83.80$ & 3.39 & $1.29-5.53$ & 1.03 & $0.23-3.58$ & 2.09 & $0.36-3.60$ \\
4 & 14 & 30.62 & $5.68-56.15$ & 3.37 & $1.35-5.54$ & 1.04 & $0.13-3.17$ & 2.55 & $0.62-5.75$ \\
Total & 93 & 27.38 & $2.51-83.80$ & 3.32 & $0.89-7.87$ & 0.98 & $0.13-3.58$ & 2.03 & $0.36-5.75$ \\
\hline
\end{tabular}

\begin{tabular}{|c|c|c|c|c|c|c|c|}
\hline \multirow{2}{*}{$\begin{array}{c}\text { Toxic } \\
\text { Elements }\end{array}$} & \multicolumn{2}{|c|}{ Domestic $(n=27)$} & \multicolumn{2}{|c|}{ Imported $(n=66)$} & \multicolumn{3}{|c|}{ Maximum Level [16-18] } \\
\hline & Mean \pm SD & Range & Mean \pm SD & Range & China & EU & CAC \\
\hline $\mathrm{Cr}$ & $28.77 \pm 14.69$ & $4.48-58.33$ & $26.71 \pm 16.43$ & $2.51-83.80$ & $-{ }^{a}$ & $-{ }^{a}$ & $-{ }^{a}$ \\
\hline As & $3.48 \pm 1.41$ & $0.89-5.19$ & $3.24 \pm 1.57$ & $0.98-7.87$ & $-{ }^{a}$ & $-\mathrm{a}$ & $-{ }^{a}$ \\
\hline $\mathrm{Cd}$ & $0.77 \pm 0.75$ & $0.13-3.17$ & $1.08 \pm 0.77$ & $0.16-3.58$ & $-{ }^{a}$ & 10 & $-{ }^{a}$ \\
\hline $\mathrm{Pb}$ & $2.13 \pm 0.96$ & $0.63-4.08$ & $1.99 \pm 1.33$ & $0.36-5.75$ & 150 & 50 & 10 \\
\hline
\end{tabular}

Table 5. Toxic elements content $(\mu \mathrm{g} / \mathrm{kg})$ in domestic and imported infant formulas.

a Not mentioned in reference. 
The contents of $\mathrm{Pb}$ in this study were below the MLs established by China (150 $\mu \mathrm{g} / \mathrm{kg})$ [16], European Union $(50 \mu \mathrm{g} / \mathrm{kg})$ [18] and CAC (10 $\mu \mathrm{g} / \mathrm{kg})$ [17]. Furthermore, the Cd content was below the ML set by the European Union (10 $\mu \mathrm{g} / \mathrm{kg}$ in infant formula) [18]. These results reveal the safety of infant formulas in China as a result of safety measures introduced by the Chinese government [37]. The average price was higher for imported infant formulas than for domestic infant formulas (74.56 vs. 52.50 yuan in Beijing market for $400 \mathrm{~g}$ infant formula) [5]. Not all families may be able to afford the high price of imported infant formulas, especially migrant workers with low income. Domestic infant formula would be an optimal choice.

The contents of $\mathrm{Cr}, \mathrm{As}, \mathrm{Pb}$ and $\mathrm{Cd}$ were $28.77 \pm 14.69,3.48 \pm 1.41,2.13 \pm 0.96$ and $0.77 \pm 0.75 \mu \mathrm{gg} / \mathrm{kg}$, respectively, in the domestic samples and $26.71 \pm 16.43,3.24 \pm 1.57,1.99 \pm 1.33$ and $1.08 \pm 0.77 \mu \mathrm{g} / \mathrm{kg}$, respectively, in the imported samples. Even though there were no significant differences in the contents of toxic elements between the domestic and imported infant formula sample ( $p>0.05)$, Cd contents were slightly lower in domestic samples.

The content of toxic elements in infant formulas reported in other studies are summarized in Table 6. The $\mathrm{Cr}$ content in our study was in accordance with the $\mathrm{Cr}$ levels reported in Tanzania $(<7-53 \mu \mathrm{g} / \mathrm{kg})$ [21], Saudi Arabia $(37 \pm 55 \mu \mathrm{g} / \mathrm{kg})$ [38], Poland $(<100 \mu \mathrm{g} / \mathrm{kg})$ [39] but higher than the levels reported in Nigeria, UK and USA [25] and lower than in Egypt [24]. As for Pb, the contents were within the range $(0.14-1,850 \mu \mathrm{g} / \mathrm{kg})$ reported by other investigators $[3,21,24,25,35,37,38]$. The $\mathrm{Cd}$ contents were similar to those reported in Tanzania $(<1-7 \mu \mathrm{g} / \mathrm{kg})$ [21], Saudi Arabia $(7 \pm 5 \mu \mathrm{g} / \mathrm{kg})$ [38], Poland $(<10 \mu \mathrm{g} / \mathrm{kg})$ [39] and Canada $(0.03-1.26 \mu \mathrm{g} / \mathrm{kg})[40]$.

Table 6. Toxic elements content in infant formulas from different countries.

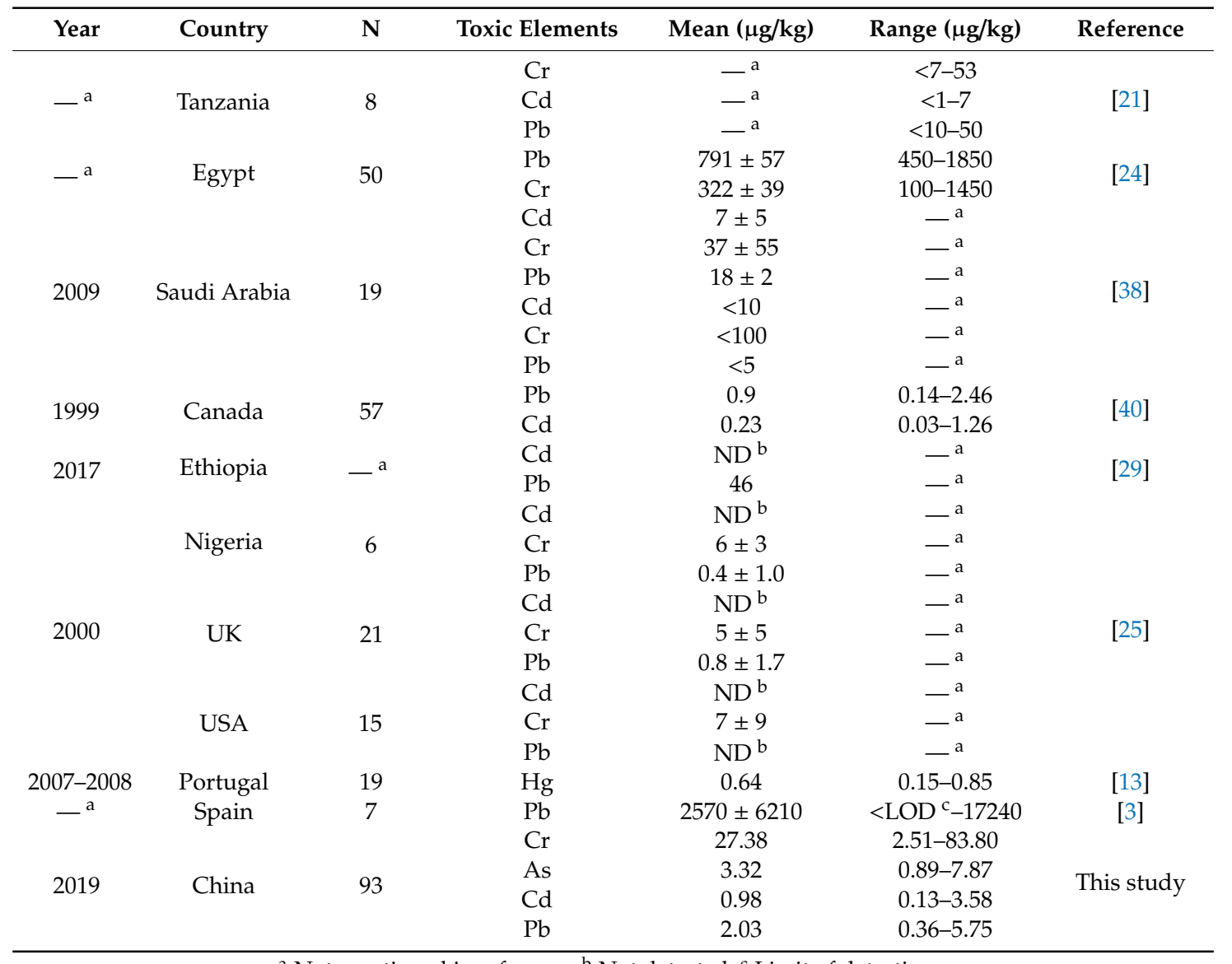

${ }^{a}$ Not mentioned in reference; ${ }^{\mathrm{b}}$ Not detected; ${ }^{\mathrm{c}}$ Limit of detection. 


\subsection{Risk Assessment of Toxic Elements Infant Formula}

Due to some key physiological differences between infants and adults, infants are far more vulnerable to the environmental contaminants, thus to the increased doses of exposure. In infants, some protection mechanisms such as blood-brain barrier, plasma protein binding capacity, enzymatic elimination mechanisms in the liver and kidneys and immune system are underdeveloped [41-44]. Infants are particularly sensitive to ingested contaminants due to larger specific surface area and efficient gastrointestinal absorption [21]. Infant formulas represent the main or only source of nutrients for infants when breastmilk is absent or insufficient. Therefore, the toxic elements in infant formulas, which may constitute a risk factor for the babies, is highly significant. It is essential to ensure their quality and safety.

Toxic elements is absorbed more in young people. It accumulates in soft tissues and over time in bones, for its long half-lives in blood and bone. The Panel on Contaminants in the Food Chain (CONTAM Panel) of European Food Safety Authority (EFSA) and the Joint Food and Agriculture Organization/World Health Organization Expert Committee on Food Additives (JECFA) identified developmental neurotoxicity in young children and cardiovascular effects and nephrotoxicity in adults as critical effects for risk assessment [15]. In 1987, the Provisional Tolerable Weekly Intake (PTWI) of Pb was established at $25 \mu \mathrm{g} / \mathrm{kg}$ bw. However, based on a dose-response analysis, the JECFA withdrew it based on a dose-response analysis [45]. In 2010, the JECFA established a provisional tolerable monthly intake (PTMI) of $25 \mu \mathrm{g} / \mathrm{kg}$ bw for Cd, equal to $5.8 \mu \mathrm{g} / \mathrm{kg}$ bw per week [46]. Inorganic arsenic (iAs) is more toxic than organic arsenic compounds [47]. Similarly, hexavalent chromium (Cr IV) is more toxic than trivalent chromium ( $\mathrm{Cr}$ III). Therefore, we assumed that $\mathrm{As}$ and $\mathrm{Cr}$ in milk were iAs and Cr (IV). In 2011, the PTWI ( $2.1 \mu \mathrm{g} / \mathrm{kg}$ bw per day) for iAs was withdrawn by Joint FAO/WHO Expert Committee on Food Additives (JECFA) [48]. The International Programme on Chemical Safety (ICPS) established the tolerable daily intake (TDI) for Cr (VI) $(0.9 \mu \mathrm{g} / \mathrm{kg}$ bw per day) for oral exposure [49]. Considering the absence of PTWI value for $\mathrm{Pb}$ and $\mathrm{As}$, we used the human health risk assessment model to characterize the potential risk of toxic elements via consumption of infant formulas from Beijing. The model was suggested to calculate health risk requirements (EDI and THQ) [50,51].

The exposure to the four toxic elements from infant formula was assessed based on the mean concentration. We estimated EDI and THQ for infants between the ages of 0.5 and $5 \mathrm{y}$, taking into account infant formula intake and average body weight (Table 7). We assumed that milk was exclusively provided by infant formula. The exposure of toxic elements for boys and girls was 0.008-0.028 and $0.008-0.031 \mu \mathrm{g} / \mathrm{kg}$ BW/day As, 0.0061-0.0152 and 0.0062-0.0165 $\mu \mathrm{g} / \mathrm{kg}$ BW/day Pb, 0.073-0.256 and $0.074-0.278 \mu \mathrm{g} / \mathrm{kg} \mathrm{BW} /$ day Cr and $0.0025-0.0085$ and $0.0025-0.0090 \mu \mathrm{g} / \mathrm{kg}$ BW/day Cd, respectively. The EDIs of $\mathrm{As}, \mathrm{Pb}, \mathrm{Cr}$ and $\mathrm{Cd}$ were lower than $\mathrm{RfD}$ references of $0.3,4.0,3.0,1.0$ and $0.5 \mu \mathrm{g} / \mathrm{kg}$ BW/day [30,32-35]. The exposure of $\mathrm{As}, \mathrm{Pb}, \mathrm{Cr}$ and $\mathrm{Cd}$ were lower than the corresponding $\mathrm{RfD}$ values.

The THQ values for boys and girls were $0.024-0.085$ and $0.025-0.093$ for As, $0.0015-0.0043$ and 0.0015-0.0046 for $\mathrm{Pb}, 0.024-0.085$ and $0.0025-0.0093$ for $\mathrm{Cr}, 0.0025-0.0083$ and $0.0025-0.0090$ for $\mathrm{Cd}$, respectively. The THQ reported by other studies are shown in Table 8. The exposure level of $\mathrm{Pb}$ was comparable to that reported in Italy [26] and lower than that reported in Nigeria, Turkey, Ethiopia and Iran [15,27-29]. The exposure of $\mathrm{Cr}$ was slightly lower than that reported in Italy [26], Turkey [28] and Ethiopia [29]. As for Cd, the exposure in this study was low compared to previous studies. The THQ of $\mathrm{As}, \mathrm{Cr}, \mathrm{Cd}$ and $\mathrm{Pb}$ was lower in this study than in Mexico.

The HI values were calculated from total THQ corresponding to each body weight at different age. The HI values are shown in Figure 1. The HI values were 0.055-0.192 for boys and 0.056-0.209 for girls. The HI value was higher for girls than boys, due to their lower body weight. The HI values were inversely associated with age and were lower than the established criteria 1 . The non-carcinogenic risk value were in the safe range, indicating that exposure of $\mathrm{As}, \mathrm{Pb}, \mathrm{Cr}$ and $\mathrm{Cd}$ from infant formulas do not represent a health risk in China. However, food producers should try their best to reduce the levels of toxic elements in infant formula [16] considering the immunodeficiency and intestinal hypoplasia for young people. 
Table 7. Estimated daily intake (EDI) and target hazard quotient (THQ) of $\mathrm{Cr}, \mathrm{As}, \mathrm{Cd}, \mathrm{Pb}$ in infants and children due to consumption of infant formula.

\begin{tabular}{ccccccccccc}
\hline \multirow{2}{*}{ Age } & Gender & $\begin{array}{c}\text { Body Weight } \\
(\mathbf{k g})[52]\end{array}$ & \multicolumn{4}{c}{ EDI } & \multicolumn{6}{c}{ THQ } \\
\cline { 4 - 11 } & & & $\mathbf{C r}$ & As & $\mathbf{C d}$ & $\mathbf{P b}$ & $\mathbf{C r}$ & As & $\mathbf{C d}$ & $\mathbf{P b}$ \\
\hline \multirow{2}{*}{0.50} & Girl & 7.30 & 0.278 & 0.031 & 0.0090 & 0.0165 & 0.093 & 0.103 & 0.0090 & 0.0041 \\
& Boy & 7.93 & 0.256 & 0.028 & 0.0083 & 0.0152 & 0.085 & 0.095 & 0.0083 & 0.0038 \\
\multirow{2}{*}{1} & Girl & 8.95 & 0.224 & 0.030 & 0.0085 & 0.0184 & 0.075 & 0.100 & 0.0085 & 0.0046 \\
& Boy & 9.65 & 0.208 & 0.028 & 0.0078 & 0.0170 & 0.069 & 0.092 & 0.0078 & 0.0043 \\
& Girl & 11.48 & 0.150 & 0.019 & 0.0057 & 0.0115 & 0.050 & 0.062 & 0.0057 & 0.0029 \\
& Boy & 12.15 & 0.142 & 0.018 & 0.0053 & 0.0108 & 0.047 & 0.059 & 0.0053 & 0.0027 \\
& Girl & 13.85 & 0.087 & 0.011 & 0.0033 & 0.0066 & 0.029 & 0.036 & 0.0033 & 0.0017 \\
3 & Boy & 14.34 & 0.084 & 0.010 & 0.0032 & 0.0064 & 0.028 & 0.035 & 0.0032 & 0.0016 \\
& Girl & 16.07 & 0.084 & 0.009 & 0.0028 & 0.0070 & 0.028 & 0.031 & 0.0028 & 0.0017 \\
& Boy & 16.34 & 0.082 & 0.009 & 0.0028 & 0.0069 & 0.027 & 0.030 & 0.0028 & 0.0017 \\
& Girl & 18.22 & 0.074 & 0.008 & 0.0025 & 0.0062 & 0.025 & 0.027 & 0.0025 & 0.0015 \\
& Boy & 18.34 & 0.073 & 0.008 & 0.0025 & 0.0061 & 0.024 & 0.027 & 0.0028 & 0.0015 \\
\hline
\end{tabular}

Table 8. EDI and THQ from other countries.

\begin{tabular}{|c|c|c|c|c|c|c|}
\hline Country & Milk Style & Metal & Stage & EDI ( $\mu \mathrm{g} / \mathrm{kg}$ bodyweight/day) & THQ & Reference \\
\hline \multirow{3}{*}{ Italy } & \multirow{3}{*}{ Infant formula } & $\mathrm{Cr}$ & & 0.51 & $-{ }^{a}$ & \multirow{3}{*}[26]{} \\
\hline & & $\mathrm{Cd}$ & Infant & 0.02 & $-{ }^{\mathrm{a}}$ & \\
\hline & & $\mathrm{Pb}$ & & 0.01 & $-{ }^{a}$ & \\
\hline \multirow[t]{3}{*}{ Nigerian } & \multirow{2}{*}{ Infant formula } & $\mathrm{Pb}$ & Infant & 1.3 & $-{ }^{a}$ & \multirow[t]{2}{*}{ [27] } \\
\hline & & $\mathrm{Cr}$ & & 20.6 & $-{ }^{a}$ & \\
\hline & \multirow{2}{*}{ Infant formula } & $\mathrm{Pb}$ & Infant & $0.10-0.15$ & $-{ }^{a}$ & \multirow{2}{*}{ [28] } \\
\hline Turkey & & $\mathrm{Cr}$ & Infant & $0.56-0.98$ & $-{ }^{a}$ & \\
\hline UK & \multirow{3}{*}{ Infant formula } & $\mathrm{Cr}$ & Infant & $5.7^{\mathrm{b}}$ & $-{ }^{a}$ & \multirow{3}{*}{ [25] } \\
\hline USA & & $\mathrm{Cr}$ & Infant & $7.7^{\mathrm{b}}$ & $-{ }^{a}$ & \\
\hline Nigeria & & $\mathrm{Cr}$ & Infant & $7.35^{\mathrm{b}}$ & $-^{a}$ & \\
\hline Ethiopia & Infant formula & $\mathrm{Pb}$ & Infant & $0.614-1.064$ & $-{ }^{a}$ & [29] \\
\hline Egypt & Powder & $\mathrm{Pb}$ & Adult & 2.26 & $-{ }^{a}$ & [24] \\
\hline Mexico & Raw milk & As & Children & $-{ }^{a}$ & $2.93-3.05$ & [27] \\
\hline \multirow{2}{*}{ Iran } & \multirow{2}{*}{ Raw milk } & $\mathrm{Pb}$ & \multirow{2}{*}{ Adult } & 0.11 & $-a$ & \multirow{2}{*}{ [15] } \\
\hline & & $\mathrm{Cd}$ & & 0.01 & $-^{a}$ & \\
\hline \multirow{4}{*}{ China } & \multirow{4}{*}{ Infant formula } & As & & $0.008-0.031$ & $0.027-0.103$ & \multirow{4}{*}{ This study } \\
\hline & & $\mathrm{Pb}$ & & $0.0061-0.0170$ & $0.0015-0.0046$ & \\
\hline & & $\mathrm{Cr}$ & Infant & $0.073-0.256$ & $0.024-0.093$ & \\
\hline & & $\mathrm{Cd}$ & & $0.0025-0.0090$ & $0.0025-0.0090$ & \\
\hline
\end{tabular}

${ }^{\mathrm{a}}$ Not mentioned in reference; ${ }^{\mathrm{b}} \mu \mathrm{g} / \mathrm{day}$.

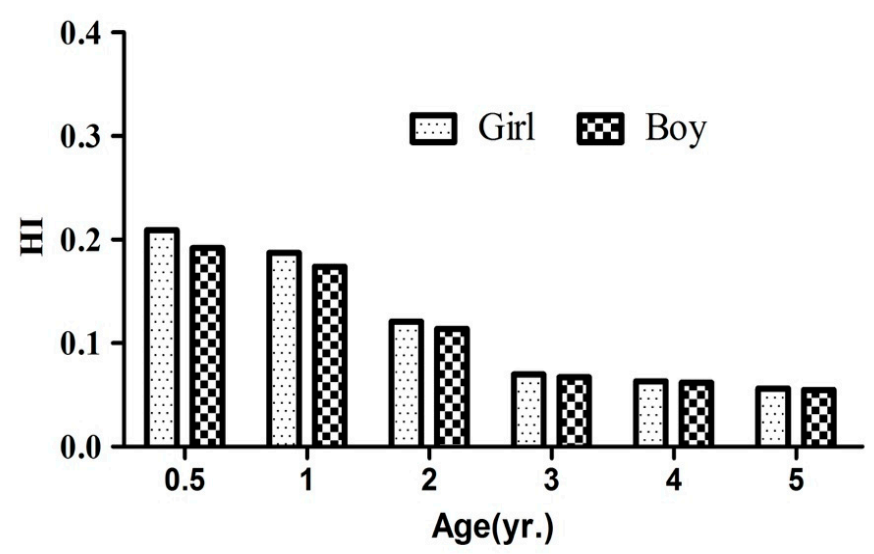

Figure 1. Hazard index (HI) of boys and girls of different age. 


\section{Conclusions}

A total of 93 infant formula samples of domestic and imported brands obtained from the Chinese market were analyzed for $\mathrm{As}, \mathrm{Cr}, \mathrm{Pb}$ and $\mathrm{Cd}$ by ICP-MS. The content of $\mathrm{Pb}$ in the samples was below the ML set by China, CAC and the European Union and the content of Cd was below the ML set by the European Union. Imported brands, which were more costly, did not have significantly lower heavy metal contents compared to domestic brands. Dietary exposure of As, $\mathrm{Cr}$ and $\mathrm{Cd}$ in infants ( $0.5-5 \mathrm{y})$ was below the corresponding RfD values. The THQ and HI values of these toxic elements were $<1$. This study suggested that the presence of toxic elements in infant formulas in Beijing, China should not pose a non-carcinogenic risk for infant health. Domestic infant formulas are preferred for infant when breastmilk is absent or insufficient. Further study is necessary to estimate macro elements, trace elements and other toxic elements in infant formulas in Beijing, to compare nutritional values not only the potential risk.

Author Contributions: Conceptualization, J.W. and N.Z.; methodology, C.S.; software, Z.W.; validation, C.S., X.Y. and S.H.; formal analysis, C.S.; investigation, C.S., N.Z. and Y.G.; resources, J.W.; data curation, Z.W.; writing—original draft preparation, C.S.; writing - review and editing, Y.G. and H.Y.; project administration, N.Z. and J.W. All authors have read and agreed to the published version of the manuscript.

Funding: This research was funded by the Risk Assessment of Environmental Pollutants in Raw Milk project (GJFP2019026) and the Agricultural Science and Technology Innovation Program (ASTIP-IAS12).

Conflicts of Interest: The authors declare no conflict of interest.

\section{References}

1. WHO. Breastfeeding. Available online: https://www.who.int/health-topics/breastfeeding\#tab=tab_1 (accessed on 10 October 2020).

2. Yang, Z.; Lai, J.; Yu, D.; Duan, Y.; Pang, X.; Jiang, S.; Bi, Y.; Wang, J.; Zhao, L.; Yin, S. Breastfeeding rates in China: A cross-sectional survey and estimate of benefits of improvement. Lancet 2016, 388, S47. [CrossRef]

3. Navarro-Blasco, I.; Alvarez-Galindo, J.I. Lead levels in retall samples infant formulae and their contribution to dietary intake of infants. Food Addit. Contam. 2005, 22, 726-734. [CrossRef] [PubMed]

4. Chinese Nutrition Society. Dietary Guidelines for Chinese Women and Children (2016); People's Sanitary Publishing Press: Beijing, China, 2018.

5. Editorial Board Member of China Dairy Yearbook. China Dairy Industry Yearbook; Agricultural Press of China: Beijing, China, 2019.

6. World Health Organization(WHO). IARC Monographs on the Identification of Carcinnogenic Hazards to Humans; Agents Classified by the IARC Monographs; IARC Scientific Publication: Lyon, France, 2020; pp. 1-128. Available online: https://monographs.iarc.fr/agents-classified-by-the-iarc/ (accessed on 30 November 2020).

7. Pandya, C.D.; Pillai, P.P.; Gupta, S.S. Lead and cadmium co-exposure mediated toxic insults on hepatic steroid metabolism and antioxidant system of adult male rats. Biol. Trace Elem. Res. 2010, 134, 307-317. [CrossRef] [PubMed]

8. Norwood, W.P.; Borgmann, U.; Dixon, D.G.; Wallace, A. Effects of metal mixtures on aquatic biota: A review of observations and methods. Hum. Ecol. Risk Assess. 2003, 9, 795-811. [CrossRef]

9. Kortenkamp, A. Ten years of mixing cocktails: A review of combination effects of endocrine-disrupting chemicals. Environ. Health Perspect. 2007, 115, 98-105. [CrossRef]

10. Su, H.; Li, Z.; Kenston, S.S.F.; Shi, H.; Wang, Y.; Song, X.; Gu, Y.; Barber, T.; Aldinger, J.; Zou, B.; et al. Joint toxicity of different heavy metal mixtures after a short-term oral repeated-administration in rats. Int. J. Environ. Res. Public Health 2017, 14, 1164. [CrossRef]

11. Daneman, R.; Rescigno, M. The Gut Immune Barrier and the Blood-Brain Barrier: Are They So Different? Immunity 2009, 31, 722-735. [CrossRef]

12. Weström, B.; Arévalo Sureda, E.; Pierzynowska, K.; Pierzynowski, S.G.; Pérez-Cano, F.J. The Immature Gut Barrier and Its Importance in Establishing Immunity in Newborn Mammals. Front. Immunol. 2020, 11. [CrossRef]

13. Martins, C.; Vasco, E.; Paixão, E.; Alvito, P. Total mercury in infant food, occurrence and exposure assessment in Portugal. Food Addit. Contam. Part B Surveill. 2013, 6, 151-157. [CrossRef] 
14. Castro-González, N.P.; Calderón-Sánchez, F.; Pérez-Sato, M.; Soní-Guillermo, E.; Reyes-Cervantes, E. Health risk due to chronic heavy metal consumption via cow's milk produced in Puebla, Mexico, in irrigated wastewater areas. Food Addit. Contam. Part B Surveill. 2019, 12, 38-44. [CrossRef]

15. Norouzirad, R.; González-Montaña, J.R.; Martínez-Pastor, F.; Hosseini, H.; Shahrouzian, A.; Khabazkhoob, M.; Ali Malayeri, F.; Moallem Bandani, H.; Paknejad, M.; Foroughi-nia, B.; et al. Lead and cadmium levels in raw bovine milk and dietary risk assessment in areas near petroleum extraction industries. Sci. Total Environ. 2018, 635, 308-314. [CrossRef]

16. National Health and Family Planning Commission. National Medical Products Administration of China National Food Safety Standard-Limits of Contaminants in Food. GB 2762-2017. 2017, pp. 1-19. Available online: https://www.cfsa.net.cn/Standard.aspx (accessed on 10 October 2020).

17. Codex Alimentarius Commission. General Standard for Contaminants and Toxins in Food and Feed. CXS193-1995 amended in 2019. 2019, pp. 1-66. Available online: http://www.fao.org/fao-who-codexalimentarius/codextexts/list-standards/en/ (accessed on 10 October 2020).

18. EC. Regulation (EC) No 1881/2006 of 19 December 2006 setting maximum levels for certain contaminants in foodstuffs. Off. J. Eur. Union 2006, L364, 1-35.

19. ATSDR. The Agency for Toxic Substances and Disease Registry's 2019 Substance Priority List; ATSDR: Atlanta, GA, USA. Available online: https://www.atsdr.cdc.gov/spl/ (accessed on 10 October 2020).

20. State Administration for Markt Regulation. Food Safety Supervision and Sampling Plan in 2019 in China. 2019. Available online: http://www.samr.gov.cn/spcjs/cjjc/qtwj/201902/t20190226_291363.html (accessed on 10 October 2020).

21. Sager, M.; McCulloch, C.R.; Schoder, D. Heavy metal content and element analysis of infant formula and milk powder samples purchased on the Tanzanian market: International branded versus black market products. Food Chem. 2018, 255, 365-371. [CrossRef] [PubMed]

22. Ljung, K.; Palm, B.; Grandér, M.; Vahter, M. High concentrations of essential and toxic elements in infant formula and infant foods-A matter of concern. Food Chem. 2011, 127, 943-951. [CrossRef] [PubMed]

23. Schilmann, $\mathrm{K}$. The toxicological extimation of the heavy metal content $(\mathrm{Cd}, \mathrm{Hg}, \mathrm{Pb})$ in food for infants and small children. Z. Ernahr. 1990, 29, 54-73.

24. Salah, F.A.A.E.; Esmat, I.A.; Bayoumi, M.A. Heavy metals residues and trace elements in milk powder marketed in Dakahlia Governorate. Int. Food Res. J. 2013, 20, 1807-1812.

25. Ikem, A.; Nwankwoala, A.; Odueyungbo, S.; Nyavor, K.; Egiebor, N. Levels of 26 elements in infant formula from USA, UK, and Nigeria by microwave digestion and ICP-OES. Food Chem. 2002, 77, 439-447. [CrossRef]

26. Bargellini, A.; Venturelli, F.; Casali, E.; Ferrari, A.; Marchesi, I.; Borella, P. Trace elements in starter infant formula: Dietary intake and safety assessment. Environ. Sci. Pollut. Res. 2018, 25, 2035-2044. [CrossRef]

27. Iwegbue, C.M.A.; Nwozo, S.O.; Overah, L.C.; Nwajei, G.E. Survey of trace element composition of commercial infant formulas in the nigerian market. Food Addit. Contam. Part. B Surveill. 2010, 3, 163-171. [CrossRef]

28. Sipahi, H.; Eken, A.; Aydın, A.; Şahin, G.; Baydar, T. Safety assessment of essential and toxic metals in infant formulas. Turk. J. Pediatr. 2015, 56, 385-391.

29. Eticha, T.; Afrasa, M.; Kahsay, G.; Gebretsadik, H. Infant Exposure to Metals through Consumption of Formula Feeding in Mekelle, Ethiopia. Int. J. Anal. Chem. 2018, 2018. [CrossRef]

30. Castro Gonzalez, N.P.; Moreno-Rojas, R.; Calderón Sánchez, F.; Moreno Ortega, A.; Juarez Meneses, M. Assessment risk to children's health due to consumption of cow's milk in polluted areas in Puebla and Tlaxcala, Mexico. Food Addit. Contam. Part. B Surveill. 2017, 10, 200-207. [CrossRef] [PubMed]

31. Qu, X.Y.; Zheng, N.; Zhou, X.W.; Li, S.L.; Wang, J.Q.; Zhang, W.J. Analysis and Risk Assessment of Seven Toxic Element Residues in Raw Bovine Milk in China. Biol. Trace Elem. Res. 2018, 183, 92-101. [CrossRef]

32. US EPA. Reference Dose (RfD): Description and Use in Health Risk Assessments. 1993. Available online: https://www.epa.gov/iris/reference-dose-rfd-description-and-use-health-risk-assessments (accessed on 10 October 2020).

33. US EPA. Chromium (VI); US EPA: Washington, DC, USA, 1998. Available online: https://iris.epa.gov/ ChemicalLanding/\&substance_nmbr=144 (accessed on 10 October 2020).

34. US EPA. Arsenic (Inorganic); US EPA: Washington, DC, USA, 1991. Available online: https://iris.epa.gov/ ChemicalLanding/\&substance_nmbr=278 (accessed on 10 October 2020). 
35. Human Health Evaluation Manual (Part A). In EPA Risk Assessment Guidance for Superfund; 1989; Volume I, p. 289. Available online: https://www.epa.gov/risk/risk-assessment-guidance-superfund-volume-i-humanhealth-evaluation-manual-supplemental (accessed on 10 October 2020).

36. Khan, K.; Khan, H.; Lu, Y.; Ihsanullah, I.; Nawab, J.; Khan, S.; Shah, N.S.; Shamshad, I.; Maryam, A. Evaluation of toxicological risk of foodstuffs contaminated with heavy metals in Swat, Pakistan. Ecotoxicol. Environ. Saf. 2014, 108, 224-232. [CrossRef] [PubMed]

37. Li, S.; Min, L.; Wang, P.; Zhang, Y.; Zheng, N.; Wang, J. Occurrence of aflatoxin M1 in pasteurized and UHT milks in China in 2014-2015. Food Control 2017, 78, 94-99. [CrossRef]

38. Al Khalifa, A.S.; Ahmad, D. Determination of key elements by ICP-OES in commercially available infant formulae and baby foods in Saudi Arabia. Afr. J. Food Sci. 2010, 4, 464-468.

39. Chajduk, E.; Pyszynska, M.; Polkowska-Motrenko, H. Determination of trace elements in infant formulas available on polish market. Biol. Trace Elem. Res. 2018, 186, 589-596. [CrossRef] [PubMed]

40. Dabeka, R.; Fouquet, A.; Belisle, S.; Turcotte, S. Lead, cadmium and aluminum in Canadian infant formulae, oral electrolytes and glucose solutions. Food Addit. Contam. Part A 2011, 28, 744-753. [CrossRef]

41. Kunter, İ.; Hürer, N.; Gülcan, H.O.; Öztürk, B.; Doğan, İ.; Şahin, G. Assessment of Aflatoxin M1 and Heavy Metal Levels in Mothers Breast Milk in Famagusta, Cyprus. Biol. Trace Elem. Res. 2017, 175, 42-49. [CrossRef]

42. Koller, K.; Brown, T.; Spurgeon, A.; Levy, L. Recent developments in low-level lead exposure and intellectual impairment in children. Environ. Health Perspect. 2004, 112, 987-994. [CrossRef]

43. Chance, G.W. Environmental contaminants and children's health: Cause for concern, time for action. Paediatr. Child Health 2001, 6, 731-743. [CrossRef] [PubMed]

44. Pohl, H.R.; Hibbs, B.F. Breast-feeding exposure of infants to environmental contaminants-A public health risk assessment viewpoint: Chlorinated dibenzodioxins and chlorinated dibenzofurans. Toxicol. Ind. Health 1996, 12, 593-611. [CrossRef] [PubMed]

45. JECFA. Lead. In Safety Evaluation of Certain Food Additives and Contaminants. Seventy-Third Meeting of the Joint FAO/WHO Expert Committee on Food Additives; WHO Food Additives Series: 64; WHO: Geneva, Switzerland, 2011; pp. 381-497.

46. JECFA. Cadmium. In Safety Evaluation of Certain food Additives and Contaminants. Seventy-Third Meeting of the Joint FAO/WHO Expert Committee on Food Additives; WHO Food Additives Series: 64; WHO: Geneva, Switzerland, 2011; pp. 305-380.

47. EFSA. Dietary exposure to inorganic arsenic in the European population. EFSA J. 2014, 12. [CrossRef]

48. World Health Organization. Evaluation of Certain Contaminants in Food; Technical Report Series; World Health Organization: Geneva, Switzerland, 2011; pp. 153-316.

49. IPCS. Principles and methods for the risk assessment of chemicals in food. International Programme on Chemical Safety. Environ. Health Criteria 2009, 240, 1-34.

50. Hashemi, M.; Sadeghi, A.; Saghi, M.; Aminzare, M.; Raeisi, M.; Rezayi, M.; Sany, S.B.T. Health Risk Assessment for Human Exposure to Trace Metals and Arsenic via Consumption of Hen Egg Collected from Largest Poultry Industry in Iran. Biol. Trace Elem. Res. 2019, 188, 485-493. [CrossRef]

51. Bortey-Sam, N.; Nakayama, S.M.M.; Ikenaka, Y.; Akoto, O.; Baidoo, E.; Yohannes, Y.B.; Mizukawa, H.; Ishizuka, M. Human health risks from metals and metalloid via consumption of food animals near gold mines in Tarkwa, Ghana: Estimation of the daily intakes and target hazard quotients (THQs). Ecotoxicol. Environ. Saf. 2015, 111, 160-167. [CrossRef]

52. WHO. Lengthheight-for-age, weight-for-age, weight-for-length, weight-for-height and body mass index-for-age Methods and development. In WHO Child Growth Standards WHO; WHO: Geneva, Switzerland, 2006.

Publisher's Note: MDPI stays neutral with regard to jurisdictional claims in published maps and institutional affiliations.

(C) 2020 by the authors. Licensee MDPI, Basel, Switzerland. This article is an open access article distributed under the terms and conditions of the Creative Commons Attribution (CC BY) license (http://creativecommons.org/licenses/by/4.0/). 